\title{
Dutch design competitions: lost in EU directives? Procurement issues of architect selections in the Netherlands
}

\section{Leentje Volker, Delft, Juriaan van Meel, Rotterdam}

\section{Introduction}

«A ritual dance». «A beauty parade». «A bureaucratic straight jacket». That is how several of the interviewees in this research qualified the current architect selections for public commissions in the Netherlands. To a certain extent, these qualifications are not surprising. Contrary to design competitions, European tender procedures have never been popular among architects. Almost straight from the start, when the EU directives on public service contracting (2004/18/EG \& 2004/17/EG) were introduced, they were associated with bureaucracy and high transaction costs. During the past several years, these frustrations seem to have increased rapidly. In the Netherlands, architects have refused to take part in architect selections, have ended up in court fighting jury rulings and fellow architects, and had the issue addressed in Dutch parliament.

This problematic situation is interesting because the Netherlands has often been portrayed as a fertile ground for young architects, giving rise to internationally acclaimed firms such as OMA, MVRDV and UN Studio. These days, however, this image no longer seems valid (BoKERN 1995). This seems in part to be caused by the strict way in which Dutch public clients interpret the EU regulations that apply to architect selections. Complaints concern the use of high, disproportional suitability criteria and time-consuming procedures, which can lead to the exclusion of young architects for public commissions. According to some architects, this way of tendering

«will ultimately destroy the basis for architecture completely. The built results of the tenders are becoming more uniform and shifting more and more towards the mediocre middle ground» (Atelier Kempe Thill 2008: 14).

Clients, in their turn, are claiming the right to select experienced and specialized firms and to conduct a careful selection process. Whether justified or not, they seem to consider this as a means to reduce the risks of budget overruns, planning delays and quality problems - which are common problems in public construction projects. While most public clients seem to acknowledge that they have a cultural role in fostering architecture, they also have an increasingly scrutinized public responsibility to create well-functioning and cost-efficient public facilities.
Neither side is very happy with the current situation. This paper discusses and analyses the current Dutch practice and argues that there are multiple ways for improving current practice tender while still complying with EU tender regulations. It closes with a brief presentation of a promising model which offers practical solutions for some of the main issues discussed herein.

\section{Methods}

The paper is a practice-oriented review, based on a literature study, four case studies, and practical experience of the authors with organising architect selections. The case-studies concerned the tender processes for the design of a town hall, a medium-sized school, the seat of a provincial government and a new faculty building for a Dutch university. In each case, the relevant actors (client representatives, architects, consultants) were interviewed and in two of the cases, the authors themselves were actively involved in the tender process.

All data were coded and analyzed in Atlas.ti, a software package to support qualitative data analysis. More information on the cases can be found in previous publications (VOLKer 2010; VolKer et al. 2008). Reflecting on these data and personal experience, the paper first gives a general overview of the current Dutch practice and relevant EU regulations in relation to the competition tradition. Next, it presents in depth the different stages of selection procedures, discussing problematic issues and possible improvements for each of the three phases.

\section{EU rules and how they are applied}

From an administrative point of view, architect selections are basically a process of purchasing services from an outside body (ArRowsmith 2005). Especially in the public sector, such processes tend to require a certain degree of formalization in order to be accountable, to avoid nepotism, to stimulate competition and to create «best value for taxpayers' money».

For countries in the European Union, the formalization of tender processes is governed by special EU directives: 2004/18/EG and 2004/17/EG, which apply to purchases or commissions above certain threshold amounts. Cur- 


\begin{tabular}{|l|rrrrrr|}
\hline & $\mathbf{2 0 0 5}$ & $\mathbf{2 0 0 6}$ & $\mathbf{2 0 0 7}$ & $\mathbf{2 0 0 8}$ & $\mathbf{2 0 0 9}$ & Average $\%$ \\
\hline Restricted EU procedure & 19 & 73 & 60 & 85 & 104 & $89 \%$ \\
Open EU procedure & 1 & 4 & 2 & 9 & 3 & $5 \%$ \\
Restricted NL procedure & 0 & 2 & 3 & 1 & 1 & $2 \%$ \\
Open NL procedure & 0 & 1 & 8 & 2 & 10 & $4 \%$ \\
Total & $\mathbf{2 0}$ & $\mathbf{8 0}$ & $\mathbf{7 3}$ & $\mathbf{9 7}$ & $\mathbf{1 1 8}$ & $\mathbf{1 0 0 \%}$ \\
\hline
\end{tabular}

Tab. 1: Number of architectural design service tenders from 16.7.2005 to 1.11.2009

Anzahl der Ausschreibungen von Leistungen im Bereich Architektur zwischen dem 16.7.2005 und dem 1.11.2009 Nombre d'appels d'offres de services architecturaux entre le 16.07.2005 et le 01.11.2009

Quelle: GeERTSE et al. 2009

rently, these thresholds are $€ 125.000$ for services bought by the central government, and $€ 193.000$ for services for other government bodies (e.g. provinces, municipalities and universities). In practice, this means that EU regulations apply to almost every substantial public design assignment, ranging from schools and town halls to hospitals and prisons, which are all critical components of the built environment we live in.

EU procedures have never been popular among architects and - to a lesser extent - clients. From the interviews conducted during this research project, it is clear that they are often considered as bureaucratic, formalistic and inflexible directives from far-away Brussels. That image, however, is not entirely justified. Close reading of the EU directives shows that they are actually quite open, providing public clients with multiple possibilities for organizing the selection process. The rules even allow the «classic» architectural competition, as long as it is based on anonymous submissions, strict pre-set evaluation criteria and expert judgement (meaning that at least a third of the jury members should be experts on architecture). Thus, it appears that EU regulations actually do not provide a barrier to the creation of a vibrant competition culture.

Interestingly enough, however, Dutch public clients have not shown much enthusiasm for organizing architectural competitions in recent years. Instead of competitions, the majority of the Dutch public sector clients prefer to use the so-called restricted tender procedure to select architects. Statistics show that in the past four years, $89 \%$ of all design-related tenders by public clients were EU restricted tender procedures (see Tab. 1, Geertse et al. 2009). Open EU procedures, such as a design competition, represent only $5 \%$ of the total of design tenders, of which many are ideas competitions without any follow up.

The Dutch interpretation of the restricted tender procedure can best be compared to the invited com- petition structure, in which a client invites a limited number of architects to develop and present a design proposal. The procedure consists of three phases: a selection phase, a tender phase and an award phase (see Fig. 1). In the selection phase, interested architectural firms can submit a request to be invited for the tender. Beforehand, the contracting authorities have to indicate which criteria they will use to evaluate the suitability of a firm and the maximum number of candidates they intend to invite (five is the minimum number according to EU directives). In the Netherlands, this «pre-selection» is most often done by setting minimum requirements concerning a firm's experience, competences and financial situation.

In the second phase («tender phase»), the preselected firms are then invited to supply the client with more detailed information about their project team and their ideas concerning the project, including a pricing proposal for their services. In most cases, Dutch clients will ask all five firms to make a concept or schematic design; sometimes the firms are asked to develop detailed design proposals including scale models and cost calculations.

During the third and final phase («award phase») the client selects a winner who is awarded the contract. The contract can be awarded based on what is called the «most economically advantageous tender» (MEAT) or the lowest price only. In architecture, almost all tenders are awarded on the MEAT principle, which means that the client evaluates which firm and/or which design proposal provides the best «value for money».

\section{Different phases, different problems}

In theory, the procedure described above could work well. Relevant EU regulations ask for little more than a transparent process and the use of criteria that are 


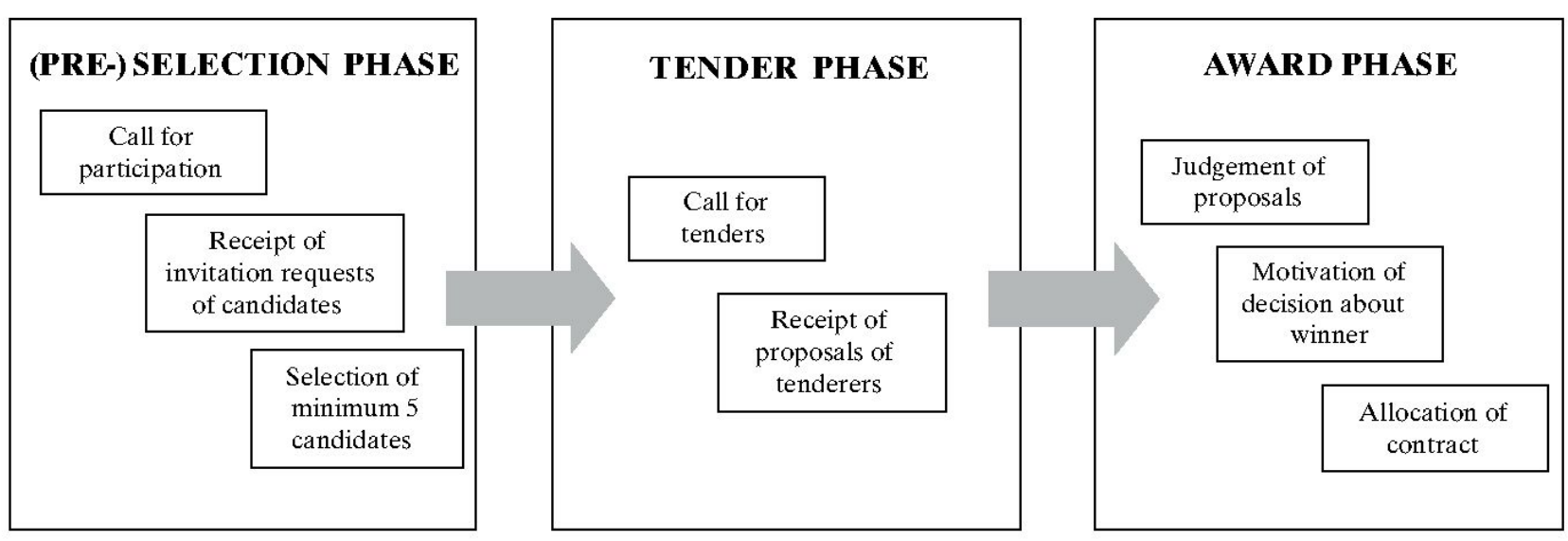

Fig. 1: Phases and activities of a restricted tender procedure Phasen und Tätigkeitsschritte einer beschränkten Ausschreibung Phases et activités d'une procédure restrictive d'appel d'offre Graphics by the authors, based on VoLKer 2010

clear, pre-defined, proportional, and as objective as possible. Reality, however, proves to be more difficult, at least in the Netherlands.

As mentioned earlier, this way of tendering is currently being heavily criticised in the Netherlands, especially by architects. An overview of the problems that are associated with the restricted tender procedure is given in Tab. 2 (based on several Dutch publications: Architectuur LokaAl 2009a; Atelier Kempe Thill 2008; Kroese et al. 2008; van Der Pol et al. 2009).

In this paper, the focus is on the subjectively-felt main issues of each of the three phases:

(1) (Pre-) selection phase: here the main issue concerns the suitability criteria that are used to determine which architectural firms are allowed to tender and which are not. The main criticism is that criteria are too strict, excluding young and small firms.

(2) Tender phase: here the main issue is the materials that the architects are asked to produce as «proof» of their competences. The main criticism is that clients are «over asking», demanding detailed design proposals while the actual design process has not yet begun.

(3) Award phase: here the main issue concerns the judgement of the qualities of the firms and their proposals. The main criticism is that judgement methods tend to be pseudo-objective and complex, looking at formalities rather than content.

These three issues are discussed below in more detail and take both practice and theory into consideration.

\subsection{The (pre-) selection phase: criteria for financial security or design talent?}

The (pre-) selection phase of a restricted EU tender is focused on limiting the «playing field». The goal is to choose the five (or more) most promising and most suitable firms with whom the client wishes to intensify relations during the tender. For this «short listing» process, clients use so-called suitability criteria. These are qualitative or quantitative criteria concerning a firm's competences, experience and/or financial situation.

The main problem with these criteria is that they tend to be very restrictive. With regard to experience, the majority of clients ask for comparable reference projects that need to have been realized in the last three to five years. For example: a client wishing to build a new school allows only firms in the selection process that have designed at least three other comparable schools within the past five years. By setting such requirements, young and new design firms do not have a chance of being awarded substantial public contracts. Furthermore, this approach pushes big and medium-sized offices into a particular market segment because they are likely to be more successful in tenders for building types in which they already have a strong track record, in this case school design (KEMPE THILl 2008).

The same problem arises when the client sets high requirements for the turnover of a firm. In most tenders, clients set a minimum requirement for the average turnover over the past three years. Such a requirement poses a problem to the large majority of Dutch architects because, in general, firms are small and have a limited turnover (Senter Novem 2009; Vogels et 
(Pre-) Selection phase

- Jumble of guidelines

- Unclear selection criteria

- Too high suitability requirements

- Too many suitability requirements

- Design activities during selection

- Too many candidates are selected for the award phase

- Unsuitable requests to participate from the candidates

\section{Tender phase}

- A request for too detailed and too elaborate design plans

- No or little financial compensation for design activities

- Lacking, illusive or strict briefs and ambition documents

- Unrealistic project budgets from clients

- No or little interaction between tenderer and client

- Fiddling about during interaction with other tenderers

- Delay during the procedure

\section{Award phase}

- Unclear or not well-considered award criteria

- Conditional offers

- Too much or too little work from tenderers

- Incomplete cost calculations from tenderers

- Indistinct user and citizen participation

- Lack of political support

- Mixture of politics and procurement

- Negotiations after announcement of the winner

Tab. 2: Overview of noted problems during restricted tenders for architectural services

Übersicht über die Probleme während einer beschränkten Ausschreibung von Leistungen im Bereich Architektur

Vue générale des problèmes survenus durant les appels d'offres de services architecturaux

al. 2008). In 2009, the average turnover requirement was $€ 862.500$ while the average firm turnover was $€ 543.000$ (GEERTSE 2010).

The use of restrictive suitability criteria can probably be explained by the clients' wish to select experienced and competent firms, fearing that young and small firms will not be able to handle the project, thereby increasing the risk of budget overruns, delays and quality problems. This is an understandable position because, as in any profession, experience builds competence. But it is also a position that can be questioned because in architecture, experience and financial success are not the same as the ability to design or the expertise to deal with specific complexities in design. Architects are proud of their capabilities to analyse complexities on an abstract level in almost any type building project and to find solutions beyond the obvious. These intellectual competences can be built by experience, but cannot be guaranteed by it. Some architects even suggest the opposite, pointing at projects like the Centre Pompidou and the Sidney Opera House, which were designed by then-virtually unknown architects - although one can also argue these are exactly the type of costly projects that have fuelled clients' fears of eccentric architects.

To deal with this issue, it is suggested here that clients take a project-by-project approach, making a distinction between innovative projects that require «naïve» entrepreneurship and fresh creativity, conventional projects that need a degree of certainty, and complex projects that ask for the involvement of specific expertise and experience. Characterizing projects, however, may be easier said than done. One way of dealing with this can be to bring in an expert that is experienced in architectural competitions, who can help inexperienced clients to develop suitable selection criteria and support the client in the actual process of short listing.

\subsection{The tender phase: looking for a plan or a partner?}

In the tender phase, the preselected firms have to deliver more detailed information about their ideas for the project and their project team for the client to reach a final decision.

In the Netherlands there is a tendency towards asking for detailed design solutions in the tender phase, sometimes including cost calculations, scale models and sustainability studies. Architects complain that this way of tendering takes a lot of time and energy although the same can be argued for the classic type of architectural competition. The Netherlands' most famous architect REM KoolHaAs commented on this issue (BENNETT 2007: 1):

«We are letting ourselves be drained of endless resources and huge amounts of ideas - all to no avail [...]. I am on a campaign now to convince the world that this kind of competition is hopeless and that we should find more efficient forms of architectural competitions against each other [...]. It is amazing how the best brains in the profession can be manœuvred into a position of complete weakness when they should be in a position of strength».

Furthermore, there is a financial reason for the complaints about demanding clients. In Dutch tenders, the 


\begin{tabular}{|c|c|c|}
\hline COMPETITION TRADITION & & PROCUREMENT PRINCIPLES \\
\hline Product & Selection subject & Partner \\
\hline Job allocation & Type ofallocation & Service allocation \\
\hline Artist & Perceived role of architect & Entrepreneur \\
\hline Object & Tenderfocus & Process \\
\hline Consultation & Type of process & Acquisition \\
\hline Design vision & Main evaluation subject & Project vision \\
\hline Cost-quality ratio & Main selection criterion & Value maximisation \\
\hline Competition regulations & Rules & Tender procedures \\
\hline Jury & Decision-making authority & Client \\
\hline Anonymous & Modus of interaction & Personal \\
\hline
\end{tabular}

Fig. 2: Tensions originating from the competing conceptions of the architect selection process Spannungen, die sich aus der Konkurrenz, unterschiedlicher Vorgehensweisen zum Auswahlverfahren von Architekten ergeben

Divergences relatives aux conceptions architecturales apparues au cours du processus de sélection Graphics by the authors, based on VoLKer 2010

financial compensation for architects' work tends to be limited, ranging from $€ 2.000$ or nothing for small projects like elementary schools, to $€ 15.000$ for complex projects like a large university building. These amounts do not cover the hours and expertise that these firms put into their design proposals. Obviously, a certain amount of costs is justifiable because it concerns an acquisition process, but the input should be in proportion to what firms can bear and in line with the size of the project. The Royal Institute of Dutch Architects estimates that participating in the award phase of a tender procedure costs about $€ 45.000$; this is about $10 \%$ of the average annual net turnover of an architectural firm ( $€ 543.000$ in 2009). For large firms, however, with an estimated average net turnover of $€ 7.3$ million, this is only $0.01 \%$ on their net turnover. These numbers demonstrate that tenders are presumably more feasible for large firms than for the average architectural firm.

The root cause of the problems in the award phase may be a lack of clarity about the actual aim of the architect selection: is it the selection of a product (a design), the selection of a service (activity of a design firm), or the selection of a partner (a designer)?

Fig. 2 presents the tensions that often appear from the different interests at play in architect selections. The left side of the figure shows the focus on the product, which is based on the client's intention to acquire a design product. This is what is currently happening in most Dutch tenders and also applies to the classic architectural competition. This approach is based on the assumption that a partner in architectural design can be chosen by judging his or her physical work or a preview of this product.

The right side of the figure shows the procurement principles and process approach. In this approach, architects are considered as entrepreneurial service providers competing for contract. Underlying the EU regulations is the idea of selecting a partner for a building project who is capable of designing the future building. Such a process focuses on maximum value for the client and therefore the client has the final decision authority - «he who pays the piper calls the tune». 
In order to know with whom the client will be doing business with, interaction is an important element in the selection process.

Both approaches in Fig. 2 are relevant to selection procedures in architecture. The problem in current practice seems to be that often clients are not aware of their aims. For them the process of architect selection is a process of sensemaking, in which they become aware of their needs and ambitions (KREINER 2006; VolKer 2010). The procurement regulations, however, presume that a tender is based on well-articulated ambitions and a detailed brief. The solution to this problem may be to look for a compromise. Instead of asking for detailed design proposals, clients could ask for schematic design proposals in combination with a vision on the process (i.e. looking at issues like user involvement, quality management and cost control). Furthermore, more possibilities for dialogue between the client and the architects during this phase may be of value. Currently, communication tends to be highly formal, consisting of an exchange of written questions and answers. Adding more possibilities for face-toface communication may give the architect a better «feel» for the client's wishes, while clients get a better view of the «soft» qualities of the architect (e.g. their ability to listen and their competences in explaining their design ideas). This, however, is likely to make the selective process more subjective. Factors such as the «likeability» of an architect will become more important while they may obscure the client's view of the architects' design competences.

4.3 Award phase: judging based on feelings or figures? In the award phase, the commissioning body has to review and evaluate all the material that has been submitted by the architectural firms. For many architects this process seems like a mysterious black box of which the outcomes are hard to predict or to influence. For clients, it tends to be a difficult process in which they have to balance intuitive judgements as well as rational analytical thinking to comply with procurement regulations (see for example HoGARTH 2005; SINCLAIR \& AshKanasy 2005).

One of the typical aspects of the current evaluation systems that are used in Dutch selection processes is the rating of different qualities with «points». Each design proposal is assessed against a rather long list of criteria, which are then weighed, and added up to a single score. This system suggests that architectural quality is measurable and scalable, which matches the requirement from $\mathrm{EU}$ regulations that evaluations should be as objective as possible.

Perhaps not surprisingly, practice shows that measuring quality is difficult. In the study cases underlying this article, only four basic levels of design quality were found: under-performance, basic performance, added value, and design excellence (VOLKer 2010). Furthermore, it was found that different qualities are overlapping and interrelated. This is in contrast with the objectivity principle that is sought in EU tender regulations, which assumes that criteria are mutually exclusive with clear boundaries and that they together fully cover the award decision.

This assumption is also in conflict with the phenomenon of compensating judgements in decision making. The concept of the «wow»- factor (DESMET et al. 2007), the «surprises» in the model of Kano (1984) and the «thrill» factor of KREINER (2007) suggests that an affective response to a design proposal can compensate deficiencies and ease choice. For the validity of the value judgement, an assessment system for design quality should therefore also incorporate possible compensation, increasing insights, and possible overlapping qualities.

Obviously, it is not easy to incorporate such complex mechanism in a procedure that is expected to be objective and transparent. One recommendation can be to use more «simple» evaluation systems, with only a limited number of criteria (allowing for more integrated judgement) and a limited number of rating levels, accompanied by written explanations (avoiding the problem of «measuring» quality). Furthermore, it can be recommended to create a bigger role for domain specific experts. Experts are usually better in complex and integral assessments than non experts (HOGARTH 2005). It should be avoided, however, that the client gets the impression that they could be overruled by experts. Instead of being the prime evaluator, it is possible to give the expert the role of facilitator, thus excluding them from the judging process, but ensuring their support in helping clients and evaluation committees to reach a clear and sound judgment.

\section{Promising developments}

Fortunately, many of the ideas mentioned above are addressed in a new tender model for architect selections which was developed by an independent nonprofit agency called Architectuur Lokaal. The model, called the «Kompas Light» (ARCHITECTUUR LOKAAL 2009b), was launched in December 2009 and it is being endorsed by major client bodies such as the Dutch central government. The digital model guides commissioning parties step by step through the relevant forms, resulting in ready-to-use guidelines for invitations to tender. Recommendations help, or urge, clients to put a focus on architectural quality and avoid the use of overly complex and restrictive criteria. 
It is important to note, however, that Kompas Light is very instrumental and offers no guarantee for solving the problem of disproportional or excessive selection criteria and vague evaluation methods. For these problems to be solved, the use of this new model has to go hand in hand with a cultural change among clients, or even the industry as a whole, that moves away from the current risk-averse attitude.

\section{Conclusion}

This article has shown that nowadays very few Dutch clients choose to organise a classic architectural competition. Instead, they prefer to use a so-called restrictive tender procedure which allows clients to invite a limited number of architects to develop and present a design proposal.

In theory, this process can be quite effective and more efficient than an architectural competition because it limits the number of participants involved. The Dutch interpretation of the procedure, however, could be improved. The most notable problems discussed here were (1) the restrictive suitability criteria in the (pre-) selection phase, (2) the extensive design proposals that are required in the tender phase, and (3) the complexity of the evaluation methods that are used for awarding the commission.

In response to these problems, this paper suggests a project-by-project approach. The right type of procedure depends on the type of project, making a distinction between innovative projects that may require «naïve» and fresh creativity, and conventional projects that may ask for certainty and risk avoidance. Selecting an architect for a high profile museum asks for a different approach than selecting a designer for a mediumsized school with a tight budget. Furthermore, it is suggested that procedures should be made less formal, providing more room for naturalistic and integrated decision making, thereby closing the gap between the formal evaluation systems, as described in the official tender documents, and the messiness of reality.

Another general recommendation concerns the involvement of experts. Currently, many selection processes are led by purchasing departments or tender consultants who may be highly knowledgeable on tender procedures but cannot support inexperienced clients evaluating the qualities of architectural firms and design proposals.

It is hoped that these recommendations, and new tools like Kompas Light, can help to re-establish the healthy architectural climate for which the Netherlands was once famous.

\section{References}

ArchitectuUr LoKaAl (2009a): EU Aanbestedingendag - publieke opdrachten architectuur \& projectontwikkeling (EU tender day - public contracts in architecture and project development). - Amsterdam: Architectuur Lokaal.

ArchitectuUr LoKaAL (2009b): Kompas Light. Amsterdam: Architectuur Lokaal, http://www.architectuuropdrachten.nl 1.12.2009.

Arrowsmith, S. (2005): The law of public and utilities procurement. - London: Sweet \& Maxwell.

Atelier Kempe Thill (2008): Naar een Nieuwe Aanbestedingscultuur - Europees Aanbesteden van Architectendiensten in Nederland (Towards a new tender culture in the Netherlands). - Rotterdam: Atelier Kempe Thill Architects and Planners.

Bennett, E. (2007): Rem demands boycott. - In: Building Design Online. - http:/www.bdonline.co.uk/news/ rem-demands-boycott/3079308.article 20.11.2010.

Bokern, A. (1995): Architecture NL. - World Trade Center Schiphol, http:/www.anneke-bokern.com/ artikel/wonderland.html 20.11.2010.

Desmet, P., Porcelijn, R. \& M.B. van Dijk (2007): Emotional design - application of a research-based design approach. - In: Knowledge Technology and Policy 20: 141-155.

GeErTse, M. (2010): Aanbestedingen architectuuropdrachten in 2009 (Tenders for architectural design services in 2009). - Amsterdam: Steunpunt Architectuuropdrachten \& Ontwerpwedstrijden.

Geertse, M., Talman, B. \& C. Jansen (2009): Aanbesteding van architectuuropdrachten sinds het BAO (Tenders for architectural services since the BAO). Amsterdam: Steunpunt Architectuuropdrachten \& Ontwerpwedstrijden.

HogarTh, R.M. (2005): Deciding analytically or trusting your intuition? The advantages and disadvantages of analytic and intuitive thought. - In: Betsch, T. \& S. HABerstroh (eds): The routines of decision making. - Mahwah, NJ: Lawrence Erlbaum Associates.

KAno, N. (1984): Attractive quality and must-be quality. - In: The Journal of the Japanese Society for Quality Control 14,2:39-48.

Kreiner, K. (2006): Architectural competitions - a case-study. - Copenhagen: Center for Management Studies of the Building Process.

Kreiner, K. (2007): Strategic choices in unknowable worlds. - Copenhagen: Center for Management Studies of the Building Process.

Kroese, R.J., MeiJer, F. \& H. Visscher (2008): De toepassing van Europese aanbestedingsregels bij architectenselecties (Implementation of procurement rules at architect selections). - Delft: Research Institute OTB.

Senter Novem (2009): Innovation iintelligence: verkenning creatieve industrie (Innovation intelligence: 
enquiries of the creative industry). - Den Haag: Senter Novem.

Sinclair, M. \& N.M. AshKanasy (2005): Intuition: myth or a decision-making tool? - In: Management Learning 36: 353-370.

Van der Pol, L., Brouwer, J., Jansen, C., Mensink, J. \& M. GeerTSE (2009): Europa en de architecten Stand van zaken in de discussie over Europese aanbestedingen van architectendiensten (Europe and the architects - the state of affairs). - Den Haag: Ministerie van VROM/Atelier Rijksbouwmeester \& Architectuur Lokaal.

Vogels, R., Mooibroek, M. \& N. De VRies (2008): Brancheonderzoek BNA 2007 (Branch Research BNA 2007). - Amsterdam: BNA - Stratus.

Volker, L. (2010): Deciding about design quality - Value judgements and decision making in the selection of architects by public clients under European tendering regulations. - Leiden: Sidestone Press.

Volker, L., Lauche, K., Heintz, J.L. \& H. de Jonge (2008): Deciding about design quality: design perception during a European tendering procedure. - In: Design Studies 29: 387-409.

\section{Summary: Dutch design competitions: lost in EU directives? Procurement issues of architect selections in the Netherlands}

This paper discusses architect selections for public commissions in the Netherlands. It shows that Dutch public clients seldom use «classic» design competitions to select architects. Instead, they use so-called restricted EU tenders which are associated with high transaction costs, disproportional suitability criteria and time-consuming procedures. These tenders are thought to lead to the exclusion of young architects and further specialisation in the architectural profession, which may, eventually, result in predictable or even mediocre architecture.

Based on a literature review, personal experience and case studies, the paper identifies three main problem areas: (1) the use of overly strict suitability criteria in the pre-selection phase; (2) the extensive design proposals that are required in the actual tender phase, and (3) the complexity of the evaluation methods that are being used for awarding the commission. After analysing these problems, the paper offers suggestions for improvement and briefly presents a promising new model, arguing that a more open, qualitative and process-oriented approach is likely to create tender procedures that are more efficient and effective.

Keywords: architecture, competition, client, procurement, the Netherlands
Zusammenfassung: Architekturwettbewerbe in den Niederlanden - verschollen zwischen EU-Richtlinien? Das öffentliche Beschaffungswesen im Bereich Architektur in den Niederlanden

Die vorliegende Arbeit diskutiert die Auswahl von Architekten für öffentliche Aufträge in den Niederlanden. Die Arbeit zeigt, dass die öffentliche Hand in den Niederlanden kaum auf «klassische» Architekturwettbewerbe zurückgreift, um Architekten auszuwählen. Stattdessen kommen meist sogenannte beschränkte EU-Ausschreibungsverfahren zum Einsatz. Diese Ausschreibungsverfahren werden häufig mit hohen Durchführungskosten, unangemessenen Eignungskriterien und hohem Zeitaufwand in Verbindung gebracht, des Weiteren wird oft angenommen, dass sie junge Architekturbüros ausschliessen und $\mathrm{zu}$ einer weiteren Spezialisierung des Architekturberufs führen, was schlussendlich vorhersehbare und mittelmässige Architekturvorschläge zur Folge hat.

Auf der Grundlage von Literaturrecherche, Fallstudien und persönlicher Erfahrung im Forschungsfeld zeigt die Arbeit drei Problemfelder auf: (1) der Einsatz von übermässig strikten Eignungskriterien in der Prä-Qualifikation, (2) der hohe Aufwand, um einen Vorschlag für die Ausschreibung zu entwickeln und (3) die Komplexität der Beurteilungsmethoden zur Ermittlung desjenigen Architekturbüros, das die Ausschreibung gewinnt. Nach der Analyse dieser Problemfelder macht die vorliegende Arbeit Verbesserungsvorschläge indem sie darlegt, dass ein offenerer, qualitativer und prozessorientierter Ansatz geeignet ist, effizientere und effektivere Ausschreibungsverfahren zu kreieren.

Schlüsselwörter: Architektur, Wettbewerb, Bauherr, Beschaffungswesen, Niederlande

\section{Résumé: Des concours d'architecture perdus dans les directives européennes? L'exemple des procédures de sélection architecturales aux Pays-Bas}

Cet article analyse le processus de sélection architectural des commissions publiques aux Pays-Bas. Il montre que les clients publics utilisent rarement les procédures de compétition «classiques» pour sélectionner les architectes et préfèrent utiliser les appels d'offres de l'Union européenne, qui présentent des coûts de transaction élevés, des critères d'aptitudes disproportionnés ainsi que des procédures demandant beaucoup de temps. Ces soumissions conduisent à l'exclusion des jeunes architectes et à une spécialisation de la profession, ce qui en définitive donne des résultats prévisibles ou souvent de médiocre qualité.

S'appuyant sur une revue de la littérature, sur l'expérience personnelle des auteurs et sur plusieurs cas d'étude, l'article identifie trois problèmes principaux: 
(1) l'usage de critères de sélection d'aptitudes trop strictes dans la phase de présélection; (2) les exigences trop importantes demandées dans la soumission proprement dite et (3) la complexité des méthodes d'évaluation utilisées dans la phase d'évaluation des projets. Après avoir analysé ces problèmes, l'article suggère certaines amélioration et présente brièvement un nouveau modèle fondé sur l'idée qu'une approche plus ouverte, plus qualitative et plus orientée sur le processus architectural est susceptible de conduire à des procédures d'appels d'offres plus efficaces.

Mots-clés: architecture, concours, clients, administration, Pays-Bas

Dr. ir. Leentje Volker, Department of Real Estate and Housing, Faculty of Architecture, Delft University of Technology, Julianalaan 134, PO Box 5043, NL-2600 GA Delft, the Netherlands. e-mail: L.Volker@tudelft.nl

Dr. ir. Juriaan van Meel, Centre for Facilities Management - Realdania Research, Building 424, Technical University of Denmark, DK-2800 Kgs. Lyngby, Denmark/ICOP Consultants, Rotterdam, the Netherlands. e-mail: vanmeel@icop.nl

Manuskripteingang/received/manuscrit reçu le 5.11.2010

Annahme zum Druck/accepted for publication/accepté pour publication: 7.3 .2011 